\title{
De barcode dokter
}

\author{
Citation for published version (APA):
}

de Baets, M. H. V. (2007). De barcode dokter. Maastricht University. https://doi.org/10.26481/spe.20071213mb

Document status and date:

Published: 13/12/2007

DOI:

10.26481/spe.20071213mb

Document Version:

Publisher's PDF, also known as Version of record

\section{Please check the document version of this publication:}

- A submitted manuscript is the version of the article upon submission and before peer-review. There can be important differences between the submitted version and the official published version of record.

People interested in the research are advised to contact the author for the final version of the publication, or visit the DOI to the publisher's website.

- The final author version and the galley proof are versions of the publication after peer review.

- The final published version features the final layout of the paper including the volume, issue and page numbers.

Link to publication

\footnotetext{
General rights rights.

- You may freely distribute the URL identifying the publication in the public portal. please follow below link for the End User Agreement:

www.umlib.nl/taverne-license

Take down policy

If you believe that this document breaches copyright please contact us at:

repository@maastrichtuniversity.nl

providing details and we will investigate your claim.
}

Copyright and moral rights for the publications made accessible in the public portal are retained by the authors and/or other copyright owners and it is a condition of accessing publications that users recognise and abide by the legal requirements associated with these

- Users may download and print one copy of any publication from the public portal for the purpose of private study or research.

- You may not further distribute the material or use it for any profit-making activity or commercial gain

If the publication is distributed under the terms of Article $25 \mathrm{fa}$ of the Dutch Copyright Act, indicated by the "Taverne" license above, 
De Barcode dokter 


\title{
De Barcode dokter
}

\begin{abstract}
Rede
In verkorte vorm uitgesproken ter gelegenheid van de aanvaarding van het ambt van hoogleraar chronische inflammatie bij neurodegeneratieve aandoeningen aan de Faculty of Health, Medicine and Life Sciences van de Universiteit Maastricht
\end{abstract}

Universiteit Maastricht (logo erbij) 
Mijnheer de Rector Magnificus, geacht College van Bestuur FHML en AZM, geachte collegae, familie, vrienden en alle toehoorders.

\section{Inleiding}

De volgende 10 jaar zullen de anamnese en het lichamelijk onderzoek, nu zo centraal in ons medisch handelen en denken, geleidelijk worden vervangen door een eenmalige sequentiebepaling van ons volledige DNA (genoom). Bij ziekte zal een geautomatiseerde spectrumanalyse gebeuren van onze lichaamsvochten met concentratiebepaling van alle eiwitten.

Deze informatie zou kunnen worden omgezet in een barcode. Dit lijkt allemaal sciencefiction, doch dit dacht men vroeger ook wanneer Leonardo Da Vinci in de $15^{\mathrm{e}}$ eeuw instrumenten en apparaten tekende die pas eeuwen later werden gerealiseerd.

Ook Jules Vernes voorzag een reis naar de maan die meer dan 100 jaar later plaats- vond door het Appollo-programma.

Evolutie in de techniek en de wetenschap gaat nu veel sneller.

Bijvoorbeeld, de sequentiebepaling van het eerste humaan genoom duurde 13 jaar, nu kan dit in enkele maanden. De oorspronkelijke kostprijs was gigantisch, doch nu wordt voorzien in het Harvard personal genoom project, om tegen het jaar 2015 kits op de markt te brengen waarbij er voor \$1000,00 in enkele uren een volledige humaan genoomsequentie zou kunnen worden verricht. 


\section{De Barcode dokter:}

In 1944 publiceerde Oswald Avery, die werkzaam was aan het Rockerfeller instituut in New York, in het tijdschrift "The Journal of Experimental Medicine" dat de genetische code vastligt in het DNA.

In 1953 werd door Watson en Crick de precieze chemische samenstelling en de 3D-structuur van onze genetische code in kaart gebracht.

Alle geneeskunde is moleculair, doch voor de meeste clinici is moleculaire geneeskunde niet-klinisch en dus niet relevant. Reeds in 1996 werd in de Lancet geschreven dat 'Those budding clinicians who move into molecular medicine do face great difficulties'. En dit heb ik geweten. Dit zijn de barcode dokters.

De barcode werd in 1948 door Johanson, Silver en Woodland gecreëerd. Er werd een patent aangevraagd in 1949 en het werd toegekend in 1952, in dezelfde periode waarin Watson en Crick het DNA-model introduceerden. Sinds 1966 worden barcodes voor commerciële doeleinden gebruikt. We kunnen ons geen supermarkt meer voorstellen waar de levensmiddelen niet gelabeld zijn met een barcode. Toch worden ook in de gezondheidszorg al barcodes gebruikt. Zoals in België, waar elke verpakking met medicijnen met een unieke barcode is gemerkt. Onderzoekers hebben ook al bijen met minibarcodes gemerkt, zodat men het gedrag van de bijen beter zal kunnen bestuderen. Zo kunnen we ook iedereen voorzien van een geïndividualiseerde barcode. Het vertalen van de individuele gegevens naar een barcode is technisch mogelijk, omdat we bij ieder individu kunnen refereren naar een referentie genotype, dat wil zeggen de bepaalde standaard -DNA-sequentie. De verschillen van een individu tegenover de standaard-DNA-sequentie ligt in de grootteorde van 1 per 1000 basen.. Dit is goed te omvatten in een barcode. Ons individueel profiel op basis van genomische data (DNA-volgorde) is nu terug te brengen tot geslacht, bloedgroeptype, huidskleur en een groot aantal erfelijke ziekten. Vooral voor deze laatste kenmerken is het nuttig om deze informatie van ieder individu te hebben.

Van een aantal bekende wetenschappers is het humane genoom bekend zoals van Jim Watson die in 1953 de DNA-code ontcijferde samen met Crick, alsook van Craig Venter (Celera Genomics). Doch niet iedereen is er op gesteld om zijn humane genoomanalyse te kennen. Een beroemdheid als Watson wilde niet weten of hij drager was van het 
Alzheimer gen. Doch voor personen die er bezwaar tegen hebben om hun humaan genoom te kennen zijn er al voldoende manieren om de individuele sequentie niet mee te delen aan het individu en het voor onderzoek beschikbaar te maken via omkeerbare identificatieprocedures.

Aan de hand van de genetische informatie vertaald in een barcode kunnen we dus ziektegenen per individu analyseren. Dit is natuurlijk onvoldoende om op het moment dat een individu met bepaalde lichamelijke klachten komt, te weten of de voorbeschiktheid tot ziekte zich al uit in bepaalde ziektepatronen. Tevoren zijn nog twee aanvullende onderzoeken noodzakelijk.

Als eerste de eiwitpatroonanalyse van de lichaamsvochten. Zo kan men bijvoorbeeld al op dit moment via een patroonanalyse van de eiwitten in het plasma van patiënten met een ovariumcarcinoom met grote zekerheid aantonen dat zij lijden aan deze ziekte.

Vervolgens willen we, wanneer er een afwijkend eiwitspectrum aanwezig is, natuurlijk weten waar nu het zieke orgaan zich bevindt.

Voor het ovarium is dit relatief makkelijk, hoewel we natuurlijk graag willen weten of het linker of rechter ovarium is aangetast. Daarvoor is een beeldanalyse noodzakelijk. Dit kan voor eierstokkanker relatief eenvoudig met een echoscopie dan wel met een CT-scan.

Voor het bestuderen van de hersenen is dit natuurlijk een stuk moeilijker. Ten eerste vooral omdat de hersenen toch goed verpakt zitten in de schedeldoos en vervolgens omdat het hersenvocht niet zo makkelijk toegankelijk is. Via een ruggenprik zou dan natuurlijk ook een eiwitspectrumanalyse kunnen worden verricht. Bij ernstige afwijkingen is het zo dat deze eiwitten ook verder in bloed aantoonbaar zijn. Wanneer er afwijkingen zijn vastgesteld kan men overgaan tot beeldvorming van de hersenen. Op dit moment gebeurt dit met verschillende instrumenten. De Europese Gemeenschap heeft echter een belangrijke investering gedaan voor het bouwen van zogenaamde hybride beeldvormende toestellen. Hierbij moeten bestaande technologieën en ook nog niet ontwikkelde technologieën worden ingebouwd in één toestel zodat men gelijktijdig beeldvorming en ook functieanalyse kan verrichten. Zo kan men met een MRI een bepaald hersenletsel aantonen en gelijktijdige chemische analyse en magnetische signalen, uitgaande van dit letsel, gebruiken om verder de aard te identificeren. Er zijn plannen voor het ontwikkelen voor zogenaamde hybride imaging apparatuur waarbij men wel 6 tot 8 verschillende technieken in één apparaat kan combineren. 
Dus de combinatie van de genoomanalyse, de eiwitanalyse en vervolgens de hybride beeldvorming moet ons in staat stellen om tot de juiste diagnose te komen.

De therapie kan vervolgens chirurgisch zijn waarbij men het letsel verwijdert, dan wel medicamenteus. Bij dit laatste is een genoomanalyse erg belangrijk omdat men dan kan bepalen of een bepaalde behandeling bij een patiënt zinvol is. Ik kom hier later op terug.

$\mathrm{Na}$ deze voor sommigen wat futuristische klinkende uiteenzetting terug naar mijn oorspronkelijke stelling waarbij ik beweer dat de anamnese en het lichamelijk onderzoek niet meer de centrale plaats zullen bekleden die ze nu hebben. Ik wil niet zeggen dat we een patiënt nooit meer gaan ondervragen, dan wel het lichamelijk onderzoek verrichten. Natuurlijk niet, maar we zullen dit wel tot het minimum kunnen beperken. De anamnese kan in ieder geval worden vervangen door het invullen van bepaalde vragenlijsten, waarbij we kunnen worden geholpen door clinical asssistant nurses die dit op een gestandaardiseerde manier kunnen verrichten.

Aan de hand van deze informatie samen met de barcode-informatie kunnen we vervolgens overgaan tot diagnosestelling via hybride imaging. Deze informatie zullen wij terugkoppelen naar de patiënt om hem -natuurlijk in lekentaal- duidelijk te maken wat hij heeft, wat voor een behandeling we zullen kiezen en wat de prognose is.

Ik ben ervan overtuigd dat na deze uiteenzetting een aantal van de clinici in deze zaal nog steeds niet overtuigd zijn van deze stelling, en dat sommigen onder $U$ nog steeds vijandig staan tegenover de hele barcode en vooral ook tegenover de barcodedokter, dus de moleculaire dokter die zich bezig houdt met translationele geneeskunde.

Hoe kunnen we deze negatieve houding tegen barcodedokters tegengaan?

1.Het eerste verwijt is dat deze dokters te weinig klinische ervaring hebben. Wanneer we teruggaan naar het voorbeeld van het ovariumcarcinoom, consulteert een vrouw met lage buikklachten haar huisarts.

Ze wordt vervolgens doorverwezen naar een gynaecoloog, die een eiwitanalyse van het serum doet waarbij de diagnose ovariumcarcinoom wordt gesteld.

Hiervoor is nog weinig klinische ervaring nodig en lichamelijk onderzoek om deze diagnose te stellen. Bovendien weet de huisarts via de 
genoomanalyse van deze patiënt dat zij de risicogenen voor het ovariumcarcinoom heeft.

2.De verleiding om veel te vroeg te beloven dat deze moleculaire geneeskunde al klinisch toepasbaar is, is een fout waar ik me nu eigenlijk ook al schuldig aan maak.

Een ander voorbeeld is de zogenaamde gentherapie waarbij al jaren geleden werd gezegd en geschreven dat wanneer een gen afwezig was men het zou kunnen vervangen. Dit is al toepasbaar voor de ziekte waarbij het immuunsysteem niet of nauwelijks functioneert op basis van een receptordefect. Bij deze patiënten kan het gen aan het beenmerg worden toegevoegd. Wanneer het gen op de foute plaats wordt ingebouwd kan er leukemie ontstaan. Dus de toepassingen van gentherapie zijn op dit moment nog heel beperkt.

3.Een derde punt is dat de barcodedokter een verstaanbare taal moet gebruiken voor de clinicus. Ook dit is een oplosbaar probleem door bepaalde afspraken te maken wat formulering betreft en in het curriculum geneeskunde de moleculaire geneeskunde te introduceren. 
Twee voorbeelden uit de kliniek:

\section{Hyperthyreoïdie}

Hyperthyreoïdie is een aandoening van de schildklier waarbij deze te veel schildklierhormoon produceert. Hierdoor wordt het metabolisme van het lichaam gestimuleerd. Dit kan een aantal symptomen veroorzaken zoals beven van de handen, toegenomen transpiratie, verhoogde onregelmatige hartslag, moeheid, gewichtsverlies en diarree.

In het midden van de vorige eeuw kon de diagnose enkel worden gesteld door het meten van het basale metabolisme. Deze diagnostiek was heel weinig specifiek, omdat tal van factoren het basale metabolisme konden verhogen zoals een stevige fietsrit. In de jaren 50 werd de laboratoriumdiagnostiek voor deze aandoening ontwikkeld in de vorm van een eiwitgebonden jodiumgehalte. Dit is een maat voor de overproductie van schildklierhormoon. Deze test was dikwijls vals positief, zoals bij mensen die werden behandeld met een jodiumhoudend contrast of tijdens de zwangerschap.

Vervolgens kon men de schildklierhormonen afzonderlijk meten, het totale T4-gehalte en het T3-gehalte en later enkel het vrije T4-gehalte, dit laatste correleert direct met de schilklierfunctie. Nadien werd de diagnostiek nog verder verfijnd middels een supergevoelige essay voor het thyroïdstimulerende hormoon, dat vanuit de hypofyse de schildklierfunctie reguleert. Nu kunnen we op een heel eenvoudige wijze bij iedere patiënt die we verdenken van een schildklierdysfunctie, (en die aantallen patiënten zijn groot), middels één test, m.n. het bepalen van het TSH-gehalte, de diagnose stellen. We kunnen stellen dat TSH een goede biomarker is voor schildklierdysfunctie.

De meest frequente oorzaak van deze schildklierdysfunctie is een autoimmuunziekte waarbij er antistoffen zijn tegen een bepaalde membraanreceptor, m.n. de TSH-receptor.

In de meerderheid van de gevallen betreft het dus een auto-immuun ziekte. We zouden aan de hand van het individueel humaan genoom ook de predispositie voor auto-immuun ziekten kunnen bepalen waardoor we bij een risicopopulatie een intermittente screening kunnen verrichten. Deze screening gebeurt nu al bijvoorbeeld bij elke pasgeborene, omdat er bij 1 op 2000 hypothyreoïdie aanwezig is op basis van een gendefect.

\section{Het grootcellig longcarcinoom}

Een ander voorbeeld is het grootcellig longcarcinoom. Hier kan de kennis van de DNA-code helpen bij de behandeling. De cellen van deze 
longkanker brengen een receptor tot expressie die gevoelig is voor een bepaalde groeifactor, de zogenaamde EGF-receptor. In 2003 werd een remmer voor deze receptor op de markt gebracht. Doch het klinische effect van dit medicijn was bedroevend laag, in de grootteorde van 10-20 $\%$. Bij deze zeldzame patiënten, waarbij de behandeling aansloeg, werd vastgesteld dat de remissie na het toedienen van dit medicijn (Gefinitib) heel langdurig was.

Bij verdere analyse van deze kleine groep goed reagerende patiënten bleek dat er een mutatie was opgetreden in deze receptor, waarbij deze receptor veel beter ging functioneren. Dus enkel in die gevallen van longkanker waar een superfunctionerende receptor voor EGFR aanwezig is, krijg je een goed succes van de behandeling. Het spreekt vanzelf dat het zinloos is om bij de grote meerderheid van deze patiënten met een grootcellig longcarcinoom een behandeling met dit medicijn te geven. Slechts een heel klein percentage van deze patiënten reageert goed op de behandeling met Gefinitib, dus ook hier is het zeer verstandig om van deze patiëntenpopulatie de genetische barcode te kennen en dus te bepalen of een patiënt al dan niet gevoelig zal zijn voor de behandeling.

$\mathrm{Na}$ deze twee klinische voorbeelden komen we tot de kern van mijn oratie, vooral de relatie tussen membraanreceptoren en chronische ontsteking.

\section{Beschrijving van de discipline en onderzoeksgebied}

Het vakgebied chronische inflammatie bij neurodegeneratieve aandoeningen bestudeert de interactie tussen het immuunsysteem en het zenuwstelsel. Stoornissen van het immuunsysteem, zoals autoimmuniteit, beïnvloeden het functioneren van het centrale en perifere zenuwstelsel. In de neurologie vormen auto-immuunziektes en antigenen gericht tegen membraanreceptoren een belangrijk gebied van aandacht binnen de auto-immuunziekten. Anderzijds kunnen psychische stoornissen ook het functioneren van het immuunsysteem beïnvloeden. Als voorbeeld wordt een depressie genoemd, waarbij een stoornis in het cytokineproductieprofiel kan worden gevonden. Neurodegeneratieve ziekten, zoals de ziekte van Parkinson, induceren een inflammatoire reactie met proliferatie van gliacellen en productie van inflammatoire cytokines .

Het centrale zenuwstelsel werd altijd beschouwd als immunologisch geprivilegeerd. De bloed-hersenbarrière is echter bij ontstekingsprocessen toegankelijk voor zowel antilichamen als 
lymfocyten. Voorts is er in het perifere zenuwstelsel een bloedhersenbarrière die na trauma of ontstekingsreactie doorlaatbaar is voor witte bloedcellen.

Een combinatie van fundamenteel en klinisch onderzoek zal nieuwe inzichten verschaffen over de interactie tussen het immuunsysteem (auto-immuunziekten) en het zenuwstelsel. Het onderzoek zal erop gericht zijn nieuwe diagnostische technieken en therapieën te ontwikkelen.

Het is niet mogelijk om dit concept van membraanreceptoren en ziekte in deze korte tijdspanne te bespreken tijdens deze oratie, maar voor geïnteresseerden is er morgen een symposium over membraanreceptoren en antistoffen waarbij ook prof. Vanda Lennon aanwezig zal zijn die dit concept in 1971 in "The Lancet" formuleerde.

Voordat ik in detail ga wil ik gaarne even het concept van een membraanreceptor toelichten. De cel is de kleinste eenheid waaruit een levend organisme bestaat. Dit bestaat uit een kern waar een genetische code in zit, dan vervolgens daaromheen een cytoplasma waarin de eiwitten worden aangemaakt en zich kleine organellen bevinden voor energieproductie van deze cel. Het geheel bevindt zich in een soort vetdruppel, het zogenaamde celmembraan. In dit celmembraan dobberen allerlei receptoren rond. Dit zijn eiwitten in de vorm van antennes die gevoelig zijn voor signalen die van buiten de cel komen.

De hypothese nu die door Vanda Lennon werd geformuleerd gaat hierover.. Door interactie van antilichamen met deze membraanreceptoren wordt een blokkade van deze receptor veroorzaakt waardoor de cel niet meer de juiste signalen ontvangt. Vervolgens treedt er beschadiging op van de cellen en dus van het weefsel ten gevolge van deze receptor-antilichaaminteractie. Dit veroorzaakt een chronische ontsteking met functionele beschadiging van het orgaan. Dit was op dat moment een geniale hypothese doch niet onderbouwd door enige vorm van experimentele benadering.

Een eerste stap in het aantonen van de correctheid van deze hypothese was het ontwikkelen van assays voor antistoffen tegen deze membraanreceptoren. Het was de verdienste van Bernard Rees Smith 
die in 1974, ook in The Lancet, een artikel publiceerde waarbij hij antistoffen kon aantonen om de schildkliercel voor de receptor van TSH. Deze antistoffen zijn verantwoordelijk voor het ontstaan van de hyperthyreoïdie, de ziekte die we daarnet hebben besproken.

Later worden nog vele andere assays ontwikkeld voor het aantonen van deze antistoffen tegen de membraanreceptoren, zo ook bij de ziekte myasthenia gravis. Bij deze ernstige spierziekte treden aanvankelijk beperkte symptomen op, zoals ptosis en diplopie. Naarmate de ziekte verder vordert treden er ook ernstige slikstoornissen, spierzwakte in armen en benen en tenslotte ook ademhalingsstoornissen op, waardoor patiënten soms langdurig moeten worden beademd. Typisch voor deze ziekte is de spontane wisseling in spierzwakte en het spontane herstel. De ziekte wordt veroorzaakt door antistoffen tegen een acetylcholinereceptor. Deze receptor is normaal verantwoordelijk voor de signaaloverdracht van de zenuw naar de spier. Blokkade van deze zenuw-spierceloverdracht heeft verlammingsverschijnselen tot gevolg.

Het is de verdienste van Jon Lindstrom die de eerste bruikbare test ontwikkelde waarbij op een relatief eenvoudige wijze de diagnose van myasthenia gravis kan worden gesteld in een vroeg stadium van de ziekte. Ook Angela Vincent en John Newsomes Davis leverden een belangrijke bijdrage door de toeposabaarheid van de assay te testen bij grote patiënten aantallen Bij ongeveer $85 \%$ van de patiënten met veralgemeende spierzwakte als gevolg van myasthenia gravis is deze antistof aantoonbaar. Hierbij is geen aanvullende diagnostiek meer noodzakelijk en kan overgegaan worden tot een behandeling. Deze behandeling bestaat er bij ernstige gevallen uit het immuunsysteem te onderdrukken, waardoor minder van deze antistoffen kunnen worden gemaakt. In theorie is dat prachtig, doch in de praktijk worden we dikwijls geconfronteerd met een zeer langzaam optredende remissie van de ziekte ondanks behandeling en de vele bijwerkingen van de huidige immuunonderdrukkende behandeling.

Om verder inzicht te krijgen in de pathogenese van de ziekte en om nieuwe behandelingsstrategieën te ontwikkelen was het noodzakelijk om een diermodel te ontwikkelen.

Het model werd bij toeval ontdekt toen Lindstrom en Patrick antilichamen produceerden tegen de acetylcholine receptor Voor deze doeleinden hadden Patrick en Lindstrom een konijn geïnjecteerd met de gezuiverde acetylcholinereceptor van de sidderaal waarbij de konijnen, zoals verwacht., antistoffen ontwikkelden tegen deze receptor. Doch deze 
konijnen vertoonden ook ernstige verlammingsverschijnselen, omdat deze antistoffen ook reageerden met de receptor van de spieren van deze konijnen.

Aanvankelijk dachten deze onderzoekers dat er een toxische stof in de receptor aanwezig was die deze konijnen ziek maakte en deed overlijden. Initieel microscopisch onderzoek van de spieren liet geen afwijkingen zien, maar door middel van de elektronenmicroscoop kon Andrew Engel de beschadiging aantonen ter hoogte van de zenuwspier-overgang. Zo ontstond het eerste diermodel voor een auto-immuun receptorziekte. We hebben een paar jaar na het ontdekken van dit diermodel ook enkele jaren in het laboratorium van Lindstrom in het Salk-instituut kunnen doorbrengen om vertrouwd te raken met dit diermodel. Om allerlei redenen werd afgestapt van konijnen en worden nu bijna uitsluitend ratten en muizen gebruikt. Dit is gebeurd omdat zij genetisch beter gekarakteriseerd zijn en waarschijnlijk ook omdat zij een iets minder grotere aaibaarheidsfactor hebben dan konijnen.

Na een verblijf van 2 jaar in de US kreeg ik in 1981 een baan in Maastricht waar ik het diermodel verder heb opgezet en ontwikkeld. 
In 1984 was ik de eerste promovendus die op dit onderwerp promoveerde hier in Maastricht. In 1987 kwam het verzoek vanuit de kliniek van dr. C.J. Höweler om samen de myasthenie patiënten te behandelen, m.n. de patiënten die hoge dosis immunosuppressiva toegediend kregen. Deze aangename samenwerking tussen de neurologen en mijzelf bij de behandeling van myasthenia gravis loopt tot op vandaag en zal nog worden uitgebreid met Aken in het AkenMaastricht neuromusculaire centrum waar ik het verder in dit betoog nog over zal hebben.

Verder over deze rattendokter die ook patiënten behandeld, (zo werd ik ooit eens genoemd door een patiënt met myasthenia gravis die via een foute route in een thuisbeademingscentrum terecht kwam en vervolgens als laatste hoop naar Maastricht kwam). Na een aangepaste behandeling met plasmaferese en immunosuppressie kon ze weer fietsen, zwemmen, enz. Ze had nu een aangenamer leven dan 14 uur per dag aan de beademing liggen. Ondanks het feit dat we de myasthenia gravis patiënten redelijk in remissie kunnen brengen, worstelen we nog steeds met de ernstige bijwerkingen, m.n. van corticosteroïden. We zijn nog steeds op zoek naar nieuwe therapieën en m.n. ook gedetailleerde analyse van de genese van dit ziektebeeld.

Dankzij de toenmalige decaan, wijlen prof. Greep, kreeg ons onderzoek een onverwachte wending. Om allerlei redenen besliste hij dat het verouderingsonderzoek een belangrijke plek moest krijgen in het Maastrichtse onderzoek. Hiervoor werd prof. Jolles en in een later stadium prof. Steinbusch aangetrokken. Zo werd ons gevraagd om onderzoek te doen naar veroudering. Als jonge onderzoeker had ik op dat moment eigenlijk niet zoveel zin om onderzoek te doen naar veroudering, want ik dacht: 'Dit is nog heel ver weg'. Toen bedacht ik het vrij simpele proefje waarbij ik experimentele myasthenia gravis zou opwekken in oude proefdieren. Tot dan gebruikte ik hiervoor jonge ratten. Via een subsidie van NWO was het mogelijk om te beschikken over ratten van 24 maanden en ouder. Uit literatuur bleek dat oude muizen gevoeliger waren voor autoimmuun-thyreoïditis. We dachten dus dat bij deze oude ratten een verhoogde gevoeligheid zou ontstaan voor myasthenia gravis. Niets was minder waar. Deze proefdieren hadden geen enkele last van de ziekteverwekkende antistoffen tegen het acetylcholine receptor die hun jonge witte broeders in dezelfde experimenten zo ernstig ziek maakten.

Bij analyse van de spieren van deze oude myasthene ratten bleken de receptoren volkomen intact, ondanks het feit dat deze oude proefdieren een grote hoeveelheid ziekteverwekkende antilichamen kregen 
toegediend. Na deze vaststelling hebben we gedurende verschillende jaren gezocht naar het mogelijke mechanisme.

De verschillen tussen oud en jong liggen niet aan het immuunsysteem, want het was al langer bekend, dat ook bij hoogbejaarde mensen het immuunsysteem perfect kan functioneren, op voorwaarde dat zij geen andere ziektes hebben en er geen zogenaamde co-morbiditeit aanwezig is. De oorzaak lag echter bij de spier. Het bleek dat oudere proefdieren $20 \%$ meer ankereiwit hebben, voor acetylcholine receptor. Hierdoor waren ze totaal ongevoelig voor de ziekteverwekkende antistoffen. Om te bewijzen dat deze verhoging van het ankereiwit en de resistentie tegen ziekten niet toevallig een associatie waren, besloten we één enkele spier in een jong dier ongevoelig te maken voor deze ziekteverwekkende antilichamen. We hebben hiervoor een nieuwe techniek gebruikt, m.n. de electroporatie. Deze techniek is ontwikkeld door de groep van Daniel Scherman in Frankrijk.

Hierbij wordt het DNA dat codeert voor het ankereiwit rapsyne in een spier geïnjecteerd en vervolgens wordt het DNA via een elektrische stroom in de spiercel geïncorporeerd. Enkele uren nadien treedt al een verhoogde productie van het ankereiwit op. Na enkele weken is de spier volkomen hersteld en blijft verhoogd rapsyne produceren. Wanneer vervolgens in de ratten ziekteverwekkende antistoffen worden toegediend blijkt deze genetisch gemanipuleerde spier volkomen ongevoelig te zijn voor deze antistof, in tegenstelling tot de niet met rapsyne behandelde spieren in hetzelfde proefdier dat duidelijk tekenen van spierzwakte vertoond. Op deze manier hebben we duidelijk aangetoond dat er een direct verband bestaat tussen de hoeveelheid rapsyne in de spier en de gevoeligheid voor myasthenia gravis. We zijn ook van plan om dit bij de mens te onderzoeken, omdat er bij myasthenie patiënten enorme verschillen bestaan in de hoeveelheid antilichamen die circuleren en de ernst van spierzwakte.

Als barcodedokter zouden we graag bij alle myasthenia gravis patiënten de rapsyne concentratie kennen en eventueel willen verhogen. Doch deze genetische transfertechnieken zijn nog niet toepasbaar bij de mens.

Onderzoek dat echter al dichter bij de toepassing voor de mens bestaat is het ontwikkelen van therapeutische antilichamen tegen membraanreceptoren. Ik verduidelijk even het principe: we hebben bij myasthenia gravis, uit antilichaam producerende witte bloedcellen, het DNA geïsoleerd dat codeert voor deze antistoffen en vervolgens deze antistoffen in celcultuur tot expressie en productie gebracht.

Antilichamen zien er uit als een vorkje met vier tanden. De tanden binden twee aan twee aan de receptor.. Aan het handvat wordt de 
biologische activiteit toegeschreven. De voornaamste ziekteverwekkende antistoffen zijn van het IgG type. Dit wordt bepaald door het handvat van de vork. Er zijn vier isotypes: 1, 2, 3 en 4. Antistoffen van het IgG1 type binden lytisch eiwitcomplement waardoor de spiercel lokaal wordt beschadigd. De antistoffen van het $\lg _{4}$ type doen dit niet. Via genetische manipulatie hebben we deze antistoffen van $\lg _{1}$ type geïsoleerd en omgevormd tot antistof van het $\lg _{4}$ type. Deze antistoffen werken beschermend tegen de ziekte myasthenia gravis in een rhesusapenmodel.

Vanuit dit onderzoek kwamen we in samenwerking met onderzoekers van bloedbank Sanquin en het bedrijf Genmab op een spoor van totaal nieuwe eigenschappen van het $\lg _{4}$ molecuul. Een antilichaam, zoals ik al zei, ziet er uit als een vork met vier tanden, bestaande uit twee symmetrische helften. In de bloedbaan kan IgG-4 gescheiden worden in twee symmetrische helften. Deze kunnen elk opnieuw een verbinding aangaan met een helft van een andere vork. Het is een compleet nieuw concept voor antilichamen. De ontwikkeling van het basaal immunologisch mechanisme werd gepubliceerd in het wetenschappelijke tijdschrift 'Science' op 14 september 2007.

$\mathrm{Er}$ is een nieuw inzicht op het gebied van $\lg _{4}$ antilichamen. Genmab heeft een unibody ontwikkeld. Door het verwijderen van een bepaald stukje van het $\lg _{4}$ antilichaam (the hinge region) ontstaat er een klein stevig half molecuul. Dit antilichaam kan als therapie gebruikt worden in sommige vormen van kanker en autoimmuunziekten.

We zetten ons onderzoek op dit gebied voort dankzij steun van het bedrijf Genmab en van de Europese gemeenschap.

In afwachting van de ontwikkeling van nieuwe therapieën, bestaat de behandeling van myasthenia gravis op dit moment nog uit een combinatie van een immuunonderdrukkende behandeling en een verwijdering van de thymus. De thymus is waarschijnlijk de oorzaak van het hele ziektebeeld. Deze laatste operatie is vrij ingrijpend en laat meestal lelijke littekens achter Dankzij de pioniersrol van prof. J.

Maessen uit Maastricht kon een robotthymectomie geïntroduceerd worden in Nederland. Hij maakt hiermee gebruik van drie robotgestuurde armen waarbij via een stereocamera de thymus in beeld kan worden gebracht. Via twee armen die voorzien zijn van een polsgewrichtje kan een delicate operatie worden uitgevoerd in de directe omgeving van het hart en de grote bloedvaten die uit het hart gaan lopen.

De laatste $2 \frac{1}{2} 2$ jaar werden al 35 patiënten uit geheel Nederland via deze ingreep geopereerd. De introductie van de robot past ook in het kader van de moderne geneeskunde en van een barcodedokter. Het woord robot is overigens door Capo Capchek in 1921 bedacht als uitdrukking 
voor een arbeidsautomaat. Het stamt van het Tsjechische robota dat arbeid betekent.

Naast toepassingen binnen de minimaal invasieve chirurgie worden robots ook gebruikt in het kader van de laboratoriumtechnologie. Het humane genoomproject is voor een groot gedeelte uitgevoerd via gerobotiseerde apparatuur. Ook Genmab maakt gebruik van gerobotiseerde apparatuur om deze nieuwe therapeutische antilichamen te screenen en te produceren.(CELLO) 


\section{Organisatie van onderzoek}

De overheveling van een deel van de eerste geldstroom naar de tweede geldstroom is gepland door minister Plasterk. Dit betekent wel het einde van onderzoekers die in hun eentje met eerste-geldstroomgelden wat onderzoek proberen te verrichten.

Anderzijds is het zo dat de basis van een productief onderzoek op niveau van een eerste geldstroom nog kleiner zal worden.

Als ik even naar mijn eigen onderzoek kijk dan zie ik dat ik met $0.5 \mathrm{fte}$ eerste geldstroom van mijzelf een tiental fte aanstuur op basis van externe middelen. De basis wordt echter verbreed door deze eerste geldstroom onder te brengen in onderzoeksscholen, zoals dat nu het geval is. Idealiter kan het onderzoek worden geleid door principal investigators, de zogenaamde PI's, die rondom zich een paar postdocs met ongeveer twee AIOS per postdoc en één of twee analisten aansturen.

Dit voorkomt het oprichten van hiërarchische structuren die elkaar via een Nederland eigen vergadercultuur van het werk houden. Hierbij kan het Amerikaanse onderzoekssysteem en ook het bedrijfsleven m.n. Microsoft als voorbeeld worden genomen. De basis van deze onderzoeksunit is te onderzoeken, niet te vergaderen. Deze onderzoekers moeten dan ook vele talenten hebben, maar de voornaamste eigenschap is de vonk die je moet zien over te slaan wanneer hij of zij met zijn collega's over onderzoek praat en die hem aanzet om bepaalde onderzoeksvragen uit te diepen, vanuit een moleculaire biologische en celbiologische analyse. Hierbij is het essentieel dat steeds de modernste apparatuur en de modernste onderzoekstechnologie beschikbaar is.

Onderzoeksvragen kunnen dankzij de nieuwe technologie en apparatuur steeds beter beantwoord worden, maar roepen steeds meer nieuwe vragen op.

Een bekend voorbeeld is het humane genoomproject. Aanvankelijk wordt de basenpaar volgorde van het DNA van een aantal mensen bepaald. Men deed er ongeveer 13 jaar over om dit eerst ruw in kaart te brengen. Op dit moment is men in staat het genoom van een individu volledig in kaart te brengen.

Deze DNA-code geeft echter onvoldoende informatie. Het zogenaamde Hugo human genoomproject is bijna volledig afgerond, maar nu is er een tweede project opgestart, het zogenaamde Hupo project, waarbij het humane proteoom, d.w.z. de eiwitten waarvoor gecodeerd wordt, geanalyseerd moet worden. Merkwaardig genoeg codeert ongeveer $5 \%$ 
van het humane genoom voor eiwitten. Dragen we de resterende 95\% zogenaamd junk-DNA mee als ballast? Het blijkt dat het junk-DNA functioneert als een regulator. Deze regulatie gebeurt via microRNA. Net zoals fysica en wiskunde aan elkaar gekoppeld zijn, is lifescience gekoppeld aan de ontwikkeling op het gebied van de moleculaire en celbiologie en computertechnologie.

Het is daarom noodzakelijk op nationaal en internationaal goede samenwerkingsverbanden te creëren en te onderhouden. Ik refereer hier aan onze samenwerking binnen de Europese gemeenschap ( MYASTHAID, EUROMYASTHENIA, DRUGCHECK).

Het oprichten van de translationele universiteit Limburg is een belangrijke ontwikkeling. Het is een kweekvijver voor jonge promovendi die ons onderzoek een extra stimulans geven. We willen hier gaarne onze samenwerking met BIOMED noemen en met name van de Universiteit Hasselt, Piet Stinissen en Veerle Somers. 


\section{Onderwijs}

Onze universiteit heeft op dit moment een 12.000 studenten verdeeld over 6 faculteiten. Het onderwijssysteem wordt over het algemeen landelijk uitstekend beoordeeld en gebeurt volgens het probleemgeoriënteerde systeem, het PGO. De universiteit pretendeert dat het niet gaat om een onderwijsmethode, maar om een manier van denken en studeren. Studenten verzamelen in samenspraak met hun tutor informatie en wisselen die nadien ook uit. Dit onderwijssysteem is bij uitstek geschikt om nieuwe ontwikkelingen in te voeren. Daarom stellen we ook voor dat de hedendaagse student al in een vroege fase van het probleemgeoriënteerde onderwijs geconfronteerd wordt met deze barcode- of moleculaire geneeskunde. Dit vergt ook een continue aanpassing en bijscholing van docenten. Deze door de moleculaire geneeskunde gestuurde andere manier van denken zal ook in de onderwijsgroepen en in het vaardigheidsonderwijs moeten worden geïntroduceerd. Studenten zullen in hun vaardigheidstoets niet meer geconfronteerd worden met het meten van het hemoglobinegehalte in het bloed middels een manuele hemoglobinemeter, maar wel met het kennisnemen van de moleculaire technologie zoals het interpreteren van de microarray-chipresultaten of de eiwitspectra.

Ik gaf al het voorbeeld van de diagnostiek van het ovariumcarcinoom waarbij door het analyseren van de serumeiwitten bij de patiënt de diagnose van ovariumcarcinoom met grote zekerheid kan worden gesteld. De student zal vertrouwd worden gemaakt met deze technologie en verder ook de voor- en nadelen en interpretatieproblemen die zich hieromtrent stellen. Via stages op de afdeling radiologie kan de student kennis nemen van de nieuwe technologieën op het gebied van de hybride imaging en de voor- en nadelen en de mogelijke pitfalls. Hiervoor is de goede kennis van de bioinformatica noodzakelijk. Ook via het studielandschap zullen studenten allerlei materialen ter beschikking worden gesteld waarin moleculaire geneeskunde wordt gedemonstreerd.

Ondanks deze hightech verbeteringen van de diagnostiek en de behandeling zal de barcodedokter nog steeds, naast zijn vakkennis, ook moeten leren met patiënten gesprekken te voeren en zal hij nog steeds een professionele houding moeten hebben en zich bewust moeten zijn van de normen en waarden van dit, weliswaar steeds evoluerend, vakgebied. 
We zullen onze toekomstige dokters moeten trainen om met de kennis van de persoonlijke genoominformatie om te gaan. In sommige centra voor prenatale diagnostiek wordt al een mRNA-analyse verricht waarbij ongeveer 65 afwijkingen worden gescreend. Hiervoor echter zijn de consequenties anders dan wanneer het gaat om een gezond individu die al weet wat voor risico's hij heeft gedurende zijn verdere leven. Dit kan enerzijds leiden tot fatalisme, maar anderzijds ook tot verstandige screening zoals voor aandoeningen als prostaatcarcinoom en andere tumoren of autoimmuunziekten.

Het is vandaag nog prematuur om succesvolle integratie van de persoonlijke genoominformatie in de routine gezondheidszorg in te schatten en de ethische sociale en klinische implicaties (referentie Mcguire, Science volume 317, pagina 1687). 


\section{Gezondheidszorg}

Het regelen van de gezondheidszorg binnen een grote organisatie als een academisch ziekenhuis is een moeilijke opdracht. In het azM heeft men de disciplinegerichte benadering voor een deel verlaten en laten plaats maken voor een integrale procesgerichte benadering van zorg, onderzoek en onderwijs. Men werkt via multidisciplinaire zorglijnen. Hierbij kan de barcodedokter een heel speciale rol spelen. Via gedetailleerde kennis van de genetische informatie zou het mogelijk moeten zijn risicoanalyses te bepalen als ook via het bepalen van eiwitspectra (proteomics) in serum of andere lichaamsfactoren van de patiënt zodat een nauwkeurige diagnose gesteld kan worden. Verdere diagnostiek kan gebeuren via het al eerder besproken hybride-imagingsysteem. Dit vergt een aanpassing van ziekenhuisstructuren en het verder uitbouwen van de apparatuur en kennis binnen de laboratoria en beeldvormende afdeling. Ook de ziekenhuisinformatiesystemen kunnen dusdanig worden aangepast dat al deze moleculaire informatie per patiënt aanwezig is.

In het kader van de reorganisatie van de gezondheidszorg binnen de azM-Move beweging is als belangrijk punt naar voren gebracht dat de patiënt centraal moet staan.

Het eerste is dat de patiënt die al gedurende geruime tijd de weg naar het ziekenhuis heeft gezocht en uiteindelijk heeft gevonden, op een goede en vriendelijke manier wordt ontvangen ( Hotelfunctie). Een mooie ontvangstbalie met competente goed geïnformeerde mensen zorgen voor deze ontvangst . Er is door het azM daarop ingespeeld door in ons inkomsthal onder het Panamerenko-vliegtuig een balie neer te zetten die patiënten in elk geval een vriendelijke ontvangst bezorgd.

Wanneer de patiënt dan uiteindelijk in de goede multidisciplinaire zorglijn terecht gekomen is, waarbij alle facetten van diagnose en behandeling aan bod zijn gekomen, wil men graag op een goede en adequate manier geïnformeerd worden over zijn ziekte en behandeling alsook de prognose.

Hierbij is ook een goed contact met de eerste lijn noodzakelijk. Dit speelt een belangrijke rol zowel bij het doorverwijzen en vervolgens terugkoppelen van de informatie en verdere behandeling naar de patiënt.

Verder blijft het terugdringen van de wachttijden toch nog een belangrijk punt van aandacht, wat mijns inziens kan opgelost worden 
door alle werkvergaderingen en andere vormen van overleg aan het einde van de dag te plannen, waarbij deze vergaderingen nooit langer dan 1 uur mogen duren.

Het is belangrijk om samen te werken en de krachten te bundelen (op het gebied van neuromusculaire gezondheidszorg is hiervoor al een landelijk netwerk ontwikkeld van academische neuromusculaire centra in perifere ziekenhuizen. Er bestaat een grote database CRAMP). Het is bekend dat patiënten niet meer vanzelfsprekend naar het dichtstbijzijnde ziekenhuis gaan, maar dat ze zoeken naar de beste gezondheidszorg en de kortste wachttijd. Belangrijk in die zorg is dat patiënten ook op zoek gaan naar een dokter die bekend is met een soms zeer zeldzaam ziektebeeld. Via het Internet komen zij hier toch wel vrij snel achter. Het verwondert mij steeds hoeveel patiënten bijvoorbeeld met PubMed kunnen omgaan, waarbij zij precies bijhouden wat een arts publiceert over de ziekte waaraan zij lijden. Er werd een belangrijke samenwerking met Aken opgestart in het kader van het Aken-Maastricht neuromusculaire centrum met professor Weis en professor Noth van de afdeling neuropathologie en neurobiologie van het Klinikum in Aken. Het is verder ook de taak van de barcodedokter om nieuwe vraagstellingen voor onderzoek te ontwikkelen en m.n. ook voor therapie en diagnostiek en therapie. Hierbij spelen de zogenaamde biologicals een belangrijke rol. Zelf hebben we ons toegelegd op het ontwikkelen van therapeutische humane antilichamen. Deze antilichamen hebben een belangrijk voordeel:

1. Ze zijn niet lichaamsvreemd.

2. Ze hebben een lange halfwaardetijd waardoor ze relatief weinig frequent worden toegediend.

Er zijn op dit moment al een groot aantal van deze producten in de gezondheidszorg aanwezig, doch de ontwikkeling van nieuwe therapeutische antilichamen m.n. betreffende de productie kent nog een aantal problemen m.n. de productiecapaciteit en de prijs is vrij hoog. Men is op de RWTH in Aken in staat om deze antilichamen in planten te produceren, waardoor het productieproces en het zuiveringsproces vereenvoudigd kunnen worden. M.n.het instituut van professor Rainer Fischer, speelt hier een belangrijke voortrekkersrol. 


\section{Dankwoord, mijn odyssee}

Ik wil aan de hand van mijn dankwoord mijn toch wat ongewone carrière schetsen. Als tienjarige jongen was ik al geïnteresseerd in de chemie. Ik werd hierin ondersteund door mijn oom, drs. José De Baets, die als klinisch chemicus me voorzag van de nodige chemicaliën zoals kaliumpermanganaat, kaliumnitraat, zwavel, koolstof. Op zichzelf allemaal vrij onschuldige stofjes. Door een aantal handboeken chemie was ik al snel in staat om buskruit te produceren. Mijn interesse in de chemie breidde zich gelukkig ook uit naar wat minder gevaarlijke stoffen.

In 1967 was mijn interesse voor de chemie nog steeds zo groot dat ik mij bij de universiteit in Gent aanmeldde voor de opleiding chemie. Mijn oom José heeft toen ingegrepen en me aangezet om medicijnen te studeren om me vandaar uit meer richting biochemie te gaan ontwikkelen. Mijn dank hiervoor aan mijn oom die me toen in deze richting heeft gestuurd.

Tijdens mijn studie geneeskunde heb ik een aantal studentassistentschappen doorlopen onder andere bij professor Werner de Potter, van het Heymans Instituut waar ik een axonaal transport in zenuwen kon bestuderen. Verder werd ik ook nog studentassistentschap bij de afdeling Oncologie bij professor Leo de Ridder. Mensen die ik allemaal wil danken omdat zij toch een belangrijke rol hebben gespeeld in mijn verdere carrière.

$\mathrm{Na}$ het starten van mijn specialisatie in de interne geneeskunde kwam ik gedurende mijn vrije tijd terecht in het laboratorium van professor Vermeulen waar ik onderzoek deed op het gebied van de endocrinologie, meer specifiek op het gebied van schildklier autoimmuunziekten waar mijn interesse op het gebied van de receptorimmunologie een aanvang maakte. Mijn dank aan de hooggeleerde heer Alex Vermeulen en André Elewaut die mij hierin begeleiden.

$\mathrm{Na}$ het afronden van mijn opleiding interne geneeskunde en mijn interessegebied endocrinologie ben ik, dankzij het verwerven van een $\mathrm{NIH}-F o g a r t h y$ fellowship en een Nato-beurs, in staat geweest om twee jaar in een top Amerikaans laboratorium te kunnen werken, m.n. de Scripps clinic and research foundation in San Diego als ook in het Salk Institute.

Ik had een project geschreven om een diermodel te ontwikkelen voor de ziekte hyperthyreodie (Ziekte van Graves) 
Nadat dit project gehonoreerd werd door NIH-Fogarthy fonds vond mijn begeleider professor W.O. Weigle dit geen goed idee. Het opzuiveren van TSH-receptoren stond op dat moment nog in de kinderschoenen. Hij introduceerde me bij professor Jon Lindstrom van het Salk Institute, die mij verder wegwijs maakte in het diermodel voor myasthenia gravis, een receptor-autoimmuunziekte. Met dank aan Jon Lindstrom en William Weigle en ook de mensen met wie ik toen in het laboratorium heb gewerkt, zoals Brett Einarson, Carol Romball, John Cooper en Socrates Tsartos met wie we nog steeds een samenwerkingsverband hebben.

In november 1981 vertrok ik toen vanuit San Diego naar Maastricht, naar de jonge faculteit geneeskunde die ik sinds 1976 toch frequent bezocht, m.n. het laboratorium pathologie en de immunologie. Met dank aan de mensen die mij toen op het laboratorium hielpen en begeleidden zoals Wieneke Vlek, Paulien Storms, Marie-José van de Gaar en later ook Mieke Henfling en Maria Vroomen.

We werkten toen allen in het toenmalige biomedisch centrum, een noodgebouw achter het oude ziekenhuis. Alle onderzoekers en analisten lunchten toen nog samen aan lange tafels, waarbij men automatisch naast hun collega-onderzoeker van een andere afdeling terecht kwam. In de lunch werden contacten gelegd met de biochemie wat resulteerde in het publiceren van een artikel in The Lancet met $\mathrm{E}$. Bevers in de groep van Professor Hemker en Zwaal.

Mijn dank aan de emeritus Van Breda Vriesman die mij de kennis van de klinische immunologie bijbracht. Over hem zijn ook de woorden die Da Vinci over de medici schreef toepasselijk: 'mi crearono e distrussono', hij maakte me...........

In mei 1997 werd ik dankzij de inspanning van professor Jaap Troost en personeelsconsulent Huub Ruyters die ik bij dezen dank, staflid bij de vakgroep Neurologie.. Hierdoor kon ik mijn klinische activiteiten verder uitbouwen in samenwerking met dr. Höweler en dr. Faber. De samenwerking met professor Spaans, ook lid van de vakgroep klinische neurowetenschappen werd eveneens hierdoor gefaciliteerd. Dit resulteerde in vele gezamenlijke publicaties op het gebied van de klinische neurofysiologie, zowel bij patiënten als dierexperimenteel. Ook Professor Jennekens wil ik gaarne danken voor zijn rol in de organisatie van het spierziektenonderzoek en mijn loopbaan in het bijzonder via ISNO en PBF.

Later verhuisde mijn onderzoekslaboratorium richting het laboratorium van professor Harry Steinbusch. 
Beste Harry, ik ben je ontzettend erkentelijk dat ik dankzij jou mijn onderzoek verder heb kunnen uitbreiden in het laboratorium van basale neurowetenschappen waar ik mijn onderzoek verder heb kunnen integreren in de bestaande onderzoekslijnen. Harry, hiervoor van harte dank.

Tot slotte wil ik nog al mijn promovendi danken zonder wie deze carrière onmogelijk was geworden en ik noem ze in volgorde: Jan Verschuuren, Ivo Graus, Astrid Hoedemakers, Fanping Meng, An de Haas, Maurice Stassen, Gunter Kenis, Mario Losen en Olaf Stuve. En ook de huidige promovendi en post docs in eerste plaats Mario Losen en Piluca Martinez, Marco Phernambucq, Sofie Janssen, Kathleen Vrolix, Annelies van Heel.

En de mensen van de technische en secretariële ondersteuning: Jorike Endert, Nicole Hoebers, Akke Spauwen en Desirée Serpenti.

Ik dank ook mijn collegas en vrienden van ons europees netwerk

Tenslotte wil ik mijn familie ook bedanken. Allereerst lieve mamma. Het is jammer dat pappa niet naast je zit te glunderen. Hij is er toch een beetje vandaag.

Aldegonde, Marleen, Patrick en Karolien bedankt voor de steun in de weinige momenten dat ik thuis ben.

Ik heb gezegd.

Postscript

Now I would like to introduced my good griend and collegue wha also made many scientific contribution to the field of autoimmune recptorelogie bij giving the final proof that antibodies from patients are able to transfer the disease to axperiemental animals, he is also a gifted doctors, an excellent cook and excellent violin player. Today he will show us onle one of his talents. He will play the violin together with Peter Caelen.

I will let them introduce themselves. 